\title{
Prospecting of popcorn hybrids for resistance to fall armyworm
}

\author{
N.C.S. Crubelati-Mulati ${ }^{1}$, C.A. Scapim ${ }^{1}$, F.A. Albuquerque ${ }^{1}$, \\ A.T. Amaral Junior ${ }^{2}$, M. Vivas $^{2}$ and M.A. Rodovalho ${ }^{1}$ \\ ${ }^{1}$ Departamento de Agronomia, Centro de Ciências Agrárias, \\ Universidade Estadual de Maringá, Maringá, PR, Brasil \\ ${ }^{2}$ Laboratório de Melhoramento Genético Vegetal, \\ Centro de Ciências e Tecnologias Agropecuárias, \\ Universidade Estadual do Norte Fluminense Darcy Ribeiro, \\ Campos dos Goytacazes, RJ, Brasil
}

Corresponding author: A.T. Amaral Junior

E-mail: amaraljr@pq.cnpq.br

Genet. Mol. Res. 13 (3): 6539-6547 (2014)

Received June 18, 2014

Accepted July 8, 2014

Published August 26, 2014

DOI http://dx.doi.org/10.4238/2014.August.26.4

\begin{abstract}
The fall armyworm, Spodoptera frugiperda, is the pest that causes the greatest economic losses for both common corn and popcorn crops, and the use of resistant plant genotypes is an important tool for integrated pest management. The goal of the present study was to evaluate the damage caused by $S$. frugiperda on single-cross popcorn hybrids under field conditions with natural infestation as well as to study the effect of 11 popcorn hybrids on the $S$. frugiperda life cycle under laboratory conditions. A completely randomized block design with 4 replicates was used for the field experiment, and a completely randomized design with 10 replicates was used for the laboratory experiment. In the field experiment, the damage caused by fall armyworm, grain yield, and popping expansion were quantified, and a diallel analysis was performed to select the best hybrids. For the laboratory experiment, caterpillars were obtained from laboratory cultures kept on an artificial diet and were fed with leaves from the
\end{abstract}


11 hybrids. Hybrids P7.0 x P9.4, P7.1 x P9.6, P7.2.0 x P9.3, P7.4.0 x P9.1 and P7.4.1 x P9.4 exhibited negative specific combining ability for injury by fall armyworm and positive specific combining ability for yield and popping expansion. In the laboratory experiment, the hybrids influenced the mean larval stage duration, mean larval mass, final larval mass, pupal stage duration, mean pupal mass, and adult longevity.

Key words: Diallel; Zea mays; Plant resistance; Spodoptera frugiperda

\section{INTRODUCTION}

Popcorn, Zea mays L, belongs to the family Poaceae, subfamily Panicoideae, and tribe Maydeae, and differs from common corn because it displays a thin capsule surrounding the grain endosperm. Popcorn plants are characterized by being smaller and more fragile than those of common corn, with narrower stems, fewer leaves, greater offspring production and higher susceptibility to pests and diseases (Catapatti et al., 2008). The agronomic traits of popcorn plants are negatively correlated with popcorn quality traits (Carpentieri-Pípolo et al., 2002; Daros et al., 2004; Rangel et al., 2011).

Considering the popularity of this product in Brazil, the production and commercialization of popcorn has been little studied. In addition, there is a lack of official data on cultivated area, yield and imported quantities (Galvão et al., 2000; Pereira and Amaral Júnior, 2001). Among the largest problems faced by the popcorn producers in Brazil is the reduced number of different cultivars and the occurrence of pests, particularly the fall armyworm, Spodoptera frugiperda (J.E. Smith, 1797) (Lepidoptera: Noctuidae) (Seifert et al., 2006).

In Brazil, the fall armyworm is estimated to be responsible for more than $25 \%$ of the losses caused by corn pests and for the majority of the 38.3 million dollars spent on insecticide spraying, resulting in an annual loss of approximately 250 million dollars (Waquil and Vilella, 2003). This insect pest may cause losses varying between 15 and 37\% in grain yield, depending on the plant development stage when the attack occurs, the cultivar, the production system and the planting site (Cruz, 1995; Sarmento et al., 2002). The losses are not related to the absence of phytosanitary treatments because the number of applications has increased over the years, and in some regions, the use of more than five insecticide applications during the crop year is common. Currently, there is a concern about the occurrence of insect populations that are resistant to chemical products, observed in some regions, and the decrease in diversity of biological control agents resulting from the inadequate use of agrochemicals (Cruz et al., 2002).

There is interest in decreasing the use of pesticides and encouraging the implementation of integrated pest management (Figueiredo et al., 2006). Several strategies are recommended for the management of this pest, including cultivation, biological, and chemical methods (Waquil et al., 2002). Plant resistance to insects is an efficient pest-control method because it results in biological, economic, and environmental benefits (Hamm and Wiseman, 1986). Among the advantages of this method is the maintenance of the insect population below the economic loss level, without causing damage to the environment and farmers (Gallo et al., 2002). Because this method does not interfere with other cultivation practices and generally displays good compatibility with other methods, it is an ideal method to be used by producers 
(Vendramim and Nishikawa, 2001).

Resistant plants have been shown to interfere with the development and behavior of the fall armyworm (Cunha et al., 2008) and may therefore contribute to a more rational use of chemicals. However, there are few studies on popcorn crops, and the present study is the first to evaluate the resistance of popcorn to the fall armyworm. The goal of the present study was to identify single-cross popcorn hybrids regarding resistance to its main pest, the fall armyworm, under field conditions with natural infestation and to evaluate the effect of 11 popcorn hybrids on the life cycle of $S$. frugiperda under laboratory conditions.

\section{MATERIAL AND METHODS}

\section{Field experiment}

The experiment was set up at Maringá, State of Paraná, at the Iguatemi experimental farm. A completely randomized block experimental design was used, with four replicates. The experimental plots consisted of a planting row $5.0 \mathrm{~m}$ long, considered to be the useful area.

The genetic material used was obtained from the Special Maize Breeding Program (Programa de Melhoramento de Milhos Especiais) developed by the Universidade Estadual de Maringá - UEM. Popcorn lines from group P7 originated from American temperate populations, whereas the lines from group P9 originated from tropical populations of the modified single-cross hybrid IAC 112. Six lines of each group were crossed according to the partial diallel cross scheme (Cruz et al., 2012), and 36 single-cross popcorn hybrids were obtained.

The agronomic traits measured were genetic resistance to the fall armyworm, grain yield and popping expansion. The genetic resistance to fall armyworm was quantified by measuring damage using a visual damage-rating scale. The fifteen central plants of each plot were used. A visual damage-rating scale with scores varying between one and six was used, where $1=$ no damage, $2=$ small scrapings (diameter smaller than $5 \mathrm{~mm}$ ), $3=$ small holes (diameter smaller than $5 \mathrm{~mm}$ ), $4=5$ - to 10 - $\mathrm{mm}$ holes, $5=$ holes bigger than $10 \mathrm{~mm}$, and $6=$ destroyed whorl. Assessments were performed 7, 10, and 14 days after seedling emergence, and the mean of the evaluations was calculated.

The grain yield was obtained by threshing the grains from all the corn cobs from each plot, correcting for $15 \%$ moisture, and expressed in $\mathrm{kg} / \mathrm{ha}$. The popping expansion, in $\mathrm{mL} / \mathrm{g}$, was analyzed using $30 \mathrm{~g}$ grain samples removed from the central-basal portion of the corn cobs. The samples were stored in a dry and cold chamber. The popping expansion was measured when the grains reached approximately $14 \%$ moisture, using an electrical popcorn maker, with automated temperature control set for $280^{\circ} \mathrm{C}$, for approximately $2 \mathrm{~min}$. The popped volume of popcorn was measured using a 2-L graduated cylinder.

An analysis of variance of the agronomic trait data obtained was performed. When a significant effect was detected, the mean squares were divided into general (GCA) and specific (SCA) combining abilities. All the statistical analyses were performed using the GENES software (Cruz, 2013). The nine best hybrids were selected (Table 1) and tested for their effect on the fall armyworm life cycle, under laboratory conditions, as described below.

\section{Laboratory experiment}

Newly hatched caterpillars obtained from laboratory mass-rearing cultures were 
placed individually into transparent acrylic Petri dishes $(9.0 \mathrm{~cm}$ diameter and $1.5 \mathrm{~cm}$ height). The caterpillars were kept under laboratory conditions $\left(25^{\circ} \pm 1{ }^{\circ} \mathrm{C} ; 70 \pm 10 \% \mathrm{RH} ; 12-\mathrm{h}\right.$ light/12-h dark photoperiod) and fed ad libitum, during the whole larval phase, with sections of 25- to 40-day-old leaves from eleven popcorn hybrids (Table 1). The experimental design was completely randomized, with ten replicates per treatment (caterpillars per hybrid).

\begin{tabular}{|c|c|c|c|c|c|}
\hline \multirow[t]{2}{*}{ Hybrids } & \multirow[t]{2}{*}{ Name of hybrid } & \multirow[t]{2}{*}{ Criteria for selection of the hybrid } & \multicolumn{3}{|c|}{ Contribution } \\
\hline & & & GY & $\mathrm{PE}$ & RFA \\
\hline P 7.4.1 X P 9.4 & UEM-1 & 2nd Highest PE & + & + & - \\
\hline P 7.2 .1 X P 9.1 & UEM-2 & 2nd Highest RFA & + & - & - \\
\hline P7.4.0 X P9.2 & UEM-3 & Highest GY & + & - & - \\
\hline P7.4.0 X P9.1 & UEM-4 & 3rd Highest GY & + & + & - \\
\hline P 7.4.0 X P 9.4 & UEM-5 & Smaller RFA & 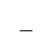 & + & + \\
\hline P $7.0 \times$ X 9.5 & UEM-6 & Highest PE & - & + & + \\
\hline P7.1 X P9.6 & UEM-7 & 2nd Highest GY & + & + & - \\
\hline P 7.4.1 X P 9.1 & UEM-8 & 3rd Highest RFA & - & + & - \\
\hline Р $7.0 \times$ P 9.3 & UEM-9 & Highest RFA & - & - & - \\
\hline
\end{tabular}

The pupae obtained were separated at hatching. Adults were maintained under the same conditions as described above, in plastic jar cages $(9 \mathrm{~cm}$ height and $18 \mathrm{~cm}$ diameter), closed with a lid of the same diameter and covered internally with newspaper, which was used as an egg-laying substrate. The couples were fed until death with a $10 \%$ honey water solution, replaced every two days. The cages were monitored daily, and the number of egg layings per female and number of eggs per laying were recorded.

All the eggs from each laying were placed on individual Petri dishes with $9 \mathrm{~cm}$ diameter $\mathrm{x} 1.5 \mathrm{~cm}$ height and were monitored for five days to determine egg viability. The egg stage duration, mean larval stage duration, final larval mass, mean larval mass, larval viability, pupal stage duration, mean pupal mass, pupal viability, adult longevity, adult deformity, number of eggs per female and total life cycle duration were determined. The data were subjected to an analysis of variance followed by a Scott-Knott test, at the $\mathrm{P}<0.05$ probability level, using the Genes software (Cruz, 2013).

\section{RESULTS AND DISCUSSION}

\section{Field assessments}

A significant effect of treatment was observed for the three measured traits, allowing the partitioning of the sums of squares into GCA and SCA. The diallel analysis revealed a significant effect of the general combining ability (GCA) both for group I (obtained from group P7, originating from American temperate populations) and for group II (obtained from group P9, originating from tropical populations of the modified single-cross hybrid IAC-112) as well as of the SCA for grain yield ( $\mathrm{kg} / \mathrm{ha}$ ) (Table 2). The overall mean yield was $1533.43 \mathrm{~kg} /$ ha, which is considered low for experimental popcorn hybrids. Vieira et al. (2009) observed a mean grain yield of $2429.4 \mathrm{~kg}$ ha and reported that these values were in agreement with those obtained by Scapim et al. (2002). 
Table 2. Summary of the analysis of variance of the partial diallel for grain yield (GY) (Kg/ha), popping expansion $(\mathrm{mL} / \mathrm{g})$ and resistance to fall armyworm (RFA) (scores).

\begin{tabular}{|c|c|c|c|c|}
\hline \multirow[t]{2}{*}{ Source of variation } & \multirow[t]{2}{*}{ Degree of freedom } & \multicolumn{3}{|c|}{ Mean square } \\
\hline & & GY & $\mathrm{PE}$ & RFA \\
\hline CROSSINGS & 35 & $500632.43 * *$ & $34.47 * *$ & $1.21 * *$ \\
\hline GCA Grup I (P7) & 5 & $912092.88 * *$ & $78.91 * *$ & $1.34 *$ \\
\hline GCA Grup II (P9) & 5 & $1365309.11 * *$ & $33.55^{*}$ & $0.71^{\mathrm{ns}}$ \\
\hline SCA IxII & 25 & $245405.00 *$ & $25.77^{*}$ & $1.29 * *$ \\
\hline ERROR & 240 & 134965.70 & 14.49 & 0.57 \\
\hline Mean & & 1533.43 & 25.70 & 2.98 \\
\hline
\end{tabular}

ns $=$ non-significant, $*$ and $* *$ significant at $\mathrm{P}<0.05$ and $\mathrm{P}<0.01$, respectively, according to the $\mathrm{F}$ test.

Both the general and the specific combining ability had significant effects on the popping expansion for the two groups, according to the $\mathrm{F}$ test, at $\mathrm{P}<0.05$ (Table 2 ). The overall mean popping expansion was $25.70 \mathrm{~mL} / \mathrm{g}$, which was very close to the $25.86 \mathrm{~mL} / \mathrm{g}$ value reported by Vieira et al. (2009). Galvão et al. (2000) state that popping expansion rates between 21 and $26 \mathrm{~mL} / \mathrm{g}$ are good, and rates higher than 26 are considered excellent. In the State of Paraná, the packing companies work with minimum rates of $30 \mathrm{~mL} / \mathrm{g}$.

A significant effect of the SCA on the reaction to the fall armyworm was observed and the effect of the general combining ability was observed for group I (Table 2). This result indicates that base populations originating from superior parents from group I are viable and will result in satisfactory gains for the selection of individuals in segregating generations. Line P7.2.1, from group I, exhibited the largest GCA effect. Lines P7.2.0, P7.4.0, and P7.4.1 also exhibited negative GCA effects (Table 3 ). It should be noted that because the parameter evaluated was resistance, lower values of combining ability were preferable.

\begin{tabular}{|c|c|c|c|}
\hline \multirow[t]{2}{*}{ Lines } & \multicolumn{3}{|c|}{ Estimates of the general combining ability } \\
\hline & GY & PE & RFA \\
\hline \multicolumn{4}{|l|}{ Group I } \\
\hline P7.0 & -236.4 & 1.964 & 0.145 \\
\hline P7.1 & 91.508 & 0.647 & 0.247 \\
\hline P7.2.0 & 86.36 & -0.753 & -0.043 \\
\hline P7.2.1 & 183.51 & 0.131 & -0.240 \\
\hline P7.4.0 & 230.13 & -1.269 & -0.070 \\
\hline P7.4.1 & -355.1 & -0.719 & -0.040 \\
\hline \multicolumn{4}{|l|}{ Group II } \\
\hline P9.1 & 212.6 & 0.314 & -0.236 \\
\hline P9.2 & -61.7 & 1.214 & 0.099 \\
\hline P9.3 & -4.8 & -1.169 & -0.175 \\
\hline P9.4 & -269.7 & 2.664 & -0.005 \\
\hline P9.5 & 235.8 & -2.469 & -0.098 \\
\hline P9.6 & -112.2 & -0.553 & 0.415 \\
\hline $\mathrm{SD}\left(\hat{\mathrm{g}}_{i}\right)$ & 68.46 & 0.70925 & 0.141 \\
\hline $\operatorname{SD}\left(\hat{\mathrm{g}}_{i}-\hat{\mathrm{g}}_{i}{ }^{\prime}\right)$ & 106.05 & 1.09877 & 0.212 \\
\hline
\end{tabular}

The observed effects of the GCA on the three traits evaluated (Table 3 ) indicate that parents P7.2.1 (group I) and P9.1 (group 2) are genetically superior and thus recommended for inclusion in the base population for selection. This recommendation is made because these parents exhibit potential for increasing the yield and popping expansion and for decreasing the damage caused by the fall armyworm. 
In addition to the identification of promising parents, based on the GSA, the diallel analysis allows an evaluation of the participation of a given parent in obtaining hybrids. Cruz et al. (2012) reported that estimating the SCA effects is useful to recommend the best pair of parents for the production of a hybrid. Hybrids P7.0 x P9.4, P7.1 x P9.6, P7.2.0 x P9.3, P7.4.0 $\mathrm{x}$ P9.1, and P7.4.1 x P9.4 stood out when considering the three traits assessed because they exhibited negative SCA effects for the damage caused by fall armyworm and positive effects for the increase in grain yield and popping expansion (Table 4).

Table 4. Estimates of the specific combining capacity for grain yield (GY), popping expansion (PE), and resistance to fall armyworm (RFA) of single-cross popcorn hybrids resulting from a partial diallel cross.

\begin{tabular}{|c|c|c|c|}
\hline \multirow[t]{2}{*}{ Hybrids } & \multicolumn{3}{|c|}{ Estimates of the specific combining capacity } \\
\hline & GY & $\mathrm{PE}$ & RFA \\
\hline P7.0 x P9.1 & -60.4 & -1.381 & 0.050 \\
\hline P7.0 x P9.2 & 194.4 & -1.064 & -0.052 \\
\hline P7.0 x P9.3 & -121.1 & -5.064 & -0.582 \\
\hline P7.0 x P9.4 & 12.3 & 1.353 & -0.225 \\
\hline P7.0 x P9.5 & -30.5 & 2.853 & 0.315 \\
\hline P7.0 x P9.6 & 5.2 & 3.303 & 0.495 \\
\hline P7.1 x P9.1 & -64.6 & -0.581 & 0.335 \\
\hline P7.1 x P9.2 & -293.3 & -1.764 & 0.263 \\
\hline P7.1 x P9.3 & -94.9 & 2.036 & 0.443 \\
\hline P7.1 x P9.4 & -135.5 & -1.047 & -0.340 \\
\hline P7.1 x P9.5 & 177.2 & -0.047 & -0.180 \\
\hline P7.1 x P9.6 & 411.2 & 1.403 & -0.520 \\
\hline P7.2.0 x P9.1 & -214.3 & 1.703 & 0.768 \\
\hline P7.2.0 x P9.2 & 10.5 & 0.520 & 0.246 \\
\hline P7.2.0 x P9.3 & 107.9 & 0.920 & -0.434 \\
\hline P7.2.0 x P9.4 & 276.6 & -4.864 & -0.287 \\
\hline P7.2.0 x P9.5 & -25.6 & 2.836 & 0.073 \\
\hline P7.2.0 x P9.6 & -155.0 & -1.114 & -0.367 \\
\hline P7.2.1 x P9.1 & 110.1 & -0.431 & -0.572 \\
\hline P7.2.1 x P9.2 & -177.4 & 0.986 & -0.984 \\
\hline P7.2.1 x P9.3 & 278.5 & 1.286 & 0.296 \\
\hline P7.2.1 x P9.4 & -37.3 & 1.503 & 0.423 \\
\hline P7.2.1 x P9.5 & 34.8 & -2.497 & -0.077 \\
\hline P7.2.1 x P9.6 & -208.8 & -0.847 & 0.913 \\
\hline P7.4.0 x P9.1 & 350.0 & 0.503 & -0.039 \\
\hline P7.4.0 x P9.2 & 483.6 & -1.281 & -0.210 \\
\hline P7.4.0 x P9.3 & -286.5 & -0.381 & -0.110 \\
\hline P7.4.0 x P9.4 & -403.9 & 0.236 & 1.106 \\
\hline P7.4.0 x P9.5 & -216.8 & 1.936 & -0.254 \\
\hline P7.4.0 x P9.6 & 73.69 & -1.014 & -0.494 \\
\hline P7.4.1 x P9.1 & -120.8 & 0.186 & -0.542 \\
\hline P7.4.1 x P9.2 & -217.7 & 2.603 & 0.736 \\
\hline P7.4.1 x P9.3 & 116.1 & 1.203 & 0.386 \\
\hline P7.4.1 x P9.4 & 287.9 & 2.820 & -0.677 \\
\hline P7.4.1 x P9.5 & 60.7 & -5.081 & 0.123 \\
\hline P7.4.1 x P9.6 & -126.2 & -1.731 & -0.027 \\
\hline $\mathrm{SD}\left(\hat{\mathrm{s}}_{i j}\right)$ & 153.07 & 1.58594 & 0.315 \\
\hline $\mathrm{SD}\left(\hat{\mathrm{s}}_{i j}-\hat{\mathrm{s}}_{i k}\right)$ & 237.14 & 2.45693 & 0.488 \\
\hline $\mathrm{SD}\left(\hat{\mathrm{S}}_{i j}-\hat{\mathrm{S}}_{k k^{\prime}}\right)$ & 237.14 & 2.45693 & 0.488 \\
\hline $\mathrm{SD}\left(\hat{\mathrm{s}}_{i j}^{\prime \prime}-\hat{\mathrm{s}}_{k l}^{k \prime}\right)$ & 212.11 & 2.19754 & 0.434 \\
\hline
\end{tabular}

Considering each trait separately, hybrid P7.4.0 x P9.2 exhibited the highest estimate of $\hat{\mathrm{s}}_{i j}(483.608)$ for grain yield. Its parent from group II exhibited the highest estimate of $\hat{\mathrm{g}}_{i}$ (230.125), but its parent from group I exhibited one of the lowest estimates (-61.708). Hybrid P7.1 x P9.6 exhibited the second-highest value of $\hat{\mathrm{s}}_{i j}$ (411.158) for grain yield, whereas its parents exhibited estimates of $\hat{\mathrm{g}}_{i}$ that were slightly low (-122.242 for group I and 91.508 for group II). Hybrid P7.4.0 x P9.1 exhibited the third-largest estimate of $\hat{\mathrm{s}}_{i j}(350.042)$ for grain yield, and 
its parents obtained good estimates for $\hat{\mathrm{g}}_{i}$ from group I (212.625) and group II (230.125) (Table 3 and 4). These three hybrids were selected to test their effects on the fall armyworm life cycle.

Hybrid P7.0 x P9.5 exhibited one of the highest estimates of $\hat{\mathrm{s}}_{i j}(2.853)$ for popping expansion (Table 4). Moreover, its group I parent exhibited a good $\hat{\mathrm{g}}_{i}$ value (1.964), while the group II parent exhibited low $\hat{\mathrm{g}}_{i}(-2.469)$. Hybrid P7.4.1 x P9.4 exhibited a good $\hat{\mathrm{s}}_{i j}$ value (2.820), while P7.4.1 exhibited a good $\hat{\mathrm{g}}_{i}$ value (2.664) and P9.4 a low $\hat{\mathrm{g}}_{i}(-0.719)$ (Tables 3 and 4$)$. Good values were observed for these two hybrids, and they were selected for the laboratory experiment.

Hybrid P7.0 x P9.3 exhibited the lowest $\hat{\mathrm{s}}_{i j}(-0.582)$ for resistance to fall armyworm, and its parent from group I exhibited a good estimate of $\hat{g}_{i}(-0.175)$. Hybrid P7.2.1 x P9.1 exhibited the second-best $\hat{\mathrm{s}}_{i j}(-0.572)$, and its parent from group I displayed a good $\hat{\mathrm{g}}_{i}$ value $(-0.236)$. Hybrid P7.4.1 x P9.1 exhibited the third-best $\hat{\mathrm{s}}_{i j}(-0.542)$, and a good $\hat{\mathrm{g}}_{i}$ value $(-0.236)$ was observed for parent P7.4.1. Considering the SCA, these three hybrids were selected for more detailed assessments under laboratory conditions. Hybrid P 7.4.0 x P 9.4, which exhibited the highest $\hat{\mathrm{s}}_{i j}$, indicating it to be the least favorable hybrid for resistance to fall armyworm, was also selected for further testing under laboratory conditions.

\section{Laboratory assessments}

The laboratory experiments consisted of bioassays to determine the biological variables of fall armyworms fed with leaves of the single-cross hybrids tested. The mean incubation period of the eggs laid by females originating from caterpillars fed with leaves from the popcorn hybrids tested was three days and did not differ between treatments. Cruz (1995) and Gallo et al. (2002) also did not observe differences for this parameter.

The overall mean larval stage duration of the caterpillars fed with leaves from popcorn hybrids was 18.5 days. Veloso et al. (1982) reported a shorter larval stage for this species on corn leaves. The shortest mean larval stage (17.6 days) was observed for the caterpillars fed with the UEM-6 hybrid, and the longest (19.4 days) was observed for the caterpillars fed with the commercial popcorn hybrid JADE (Table 5). Lower means were observed with hybrids UEM-1, UEM-4, UEM-5, UEM-6, UEM-7, and IAC 112 than with the remaining hybrids tested.

Table 5. Mean larval stage duration (MLSD), larval final mass (g) (LFM), mean larval mass (g) (MLM), pupal stage duration (days) (PSD), mean pupal mass (g) (MPM), adult longevity (days) (AL) and total life-cycle duration (days) (TLCD) for Spodoptera frugiperda caterpillars fed with leaves from popcorn hybrids UEM-1, UEM-2, UEM-3, UEM-4, UEM-5, UEM-6, UEM-7, UEM-8, UEM-9, IAC 112 and JADE. Maringá, Paraná, 2009.

\begin{tabular}{|c|c|c|c|c|c|c|c|}
\hline Hybrids & MLSD & LFM & MLM & PSD & MPM & $\mathrm{AL}$ & TLCD \\
\hline UEM-1 & $17.9^{\mathrm{A} *}$ & $0.38^{\mathrm{A}}$ & $0.12^{\mathrm{B}}$ & $10.0^{\mathrm{A}}$ & $0.18^{\mathrm{B}}$ & $4.4^{\mathrm{A}}$ & $35.3^{\mathrm{A}}$ \\
\hline UEM-2 & $18.7^{\mathrm{B}}$ & $0.46^{\mathrm{B}}$ & $0.12^{\mathrm{B}}$ & $10.3^{\mathrm{B}}$ & $0.19^{\mathrm{B}}$ & $4.5^{\mathrm{A}}$ & $35.3^{\mathrm{A}}$ \\
\hline UEM-3 & $19.2^{\mathrm{B}}$ & $0.33^{\mathrm{A}}$ & $0.11^{\mathrm{A}}$ & $10.9^{\mathrm{B}}$ & $0.16^{\mathrm{A}}$ & $4.5^{\mathrm{A}}$ & $35.3^{\mathrm{A}}$ \\
\hline UEM-4 & $18.0^{\mathrm{A}}$ & $0.41^{\mathrm{B}}$ & $0.13^{\mathrm{B}}$ & $10.6^{\mathrm{B}}$ & $0.19^{\mathrm{B}}$ & $4.7^{\mathrm{A}}$ & $35.3^{\mathrm{A}}$ \\
\hline UEM-5 & $18.0^{\mathrm{A}}$ & $0.38^{\mathrm{A}}$ & $0.12^{\mathrm{B}}$ & $9.56^{\mathrm{A}}$ & $0.17^{\mathrm{A}}$ & $4.3^{\mathrm{A}}$ & $35.3^{\mathrm{A}}$ \\
\hline UEM-6 & $17.6^{\mathrm{A}}$ & $0.39^{\mathrm{A}}$ & $0.13^{\mathrm{B}}$ & $9.18^{\mathrm{A}}$ & $0.21^{\mathrm{B}}$ & $5.4^{\mathrm{B}}$ & $35.3^{\mathrm{A}}$ \\
\hline UEM-7 & $18.4^{\mathrm{A}}$ & $0.42^{\mathrm{B}}$ & $0.13^{\mathrm{B}}$ & $10.9^{\mathrm{B}}$ & $0.19^{\mathrm{B}}$ & $3.9^{\mathrm{A}}$ & $35.3^{\mathrm{A}}$ \\
\hline UEM-8 & $19.0^{\mathrm{B}}$ & $0.41^{\mathrm{B}}$ & $0.11^{\mathrm{A}}$ & $11.0^{\mathrm{B}}$ & $0.19^{\mathrm{B}}$ & $4.1^{\mathrm{A}}$ & $35.3^{\mathrm{A}}$ \\
\hline UEM-9 & $19.0^{\mathrm{B}}$ & $0.38^{\mathrm{A}}$ & $0.11^{\mathrm{A}}$ & $10.6^{\mathrm{B}}$ & $0.18^{\mathrm{B}}$ & $4.2^{\mathrm{A}}$ & $35.3^{\mathrm{A}}$ \\
\hline IAC 112 & $18.1^{\mathrm{A}}$ & $0.42^{\mathrm{B}}$ & $0.12^{\mathrm{B}}$ & $11.1^{\mathrm{B}}$ & $0.21^{\mathrm{B}}$ & $4.3^{\mathrm{A}}$ & $35.3^{\mathrm{A}}$ \\
\hline JADE & $19.4^{\mathrm{B}}$ & $0.39^{\mathrm{A}}$ & $0.13^{\mathrm{B}}$ & $10.4^{\mathrm{B}}$ & $0.18^{\mathrm{A}}$ & $4.7^{\mathrm{A}}$ & $35.3^{\mathrm{A}}$ \\
\hline $\mathrm{Cv}(\%)$ & 6.53 & 16.72 & 11.65 & 8.74 & 12.9 & 18.27 & 5.32 \\
\hline
\end{tabular}

*Means followed by the same superscript letter, for the same variable, constitute a homogeneous group according to the Scott-Knott test, at $\mathrm{P}<0.05$. 
The final larval mass corresponds to the mass gained during the larval stage, i.e., the body mass accumulated during larval development. The overall mean final mass of the caterpillars fed with leaves from the popcorn hybrids tested was $0.395 \mathrm{~g}$. Veloso et al. (1982) studied the damage by $S$. frugiperda in corn and cotton and reported $0.410 \mathrm{~g}$ for the mean mass of caterpillars at the peak of their development. Thus, the mean final larval mass decreased, and hybrids UEM-1, UEM-3, UEM-5, UEM-6, UEM-9, and the control JADE were the ones with the lowest means (Table 5). The lowest final mass was observed in the caterpillars fed with hybrid UEM-3, and the highest final mass was observed in the caterpillars fed with hybrid UEM-2 (Table 5). The overall mean larval mass was $0.123 \mathrm{~g}$. The lowest larval mass was observed for the caterpillars fed with hybrid UEM-3, and the highest larval mass was observed for the caterpillars fed with hybrid UEM-6. The caterpillars fed with hybrids UEM-3, UEM-8 and UEM-9 exhibited significantly lower mean mass values than the caterpillars in the other treatments (Table 5).

The larval viability was higher than $60 \%$ for all the treatments. The highest value, $100 \%$, was observed for hybrids UEM-1, UEM-4, UEM-6, and JADE, whereas the lowest values were found for hybrids UEM-3 (60\%) and IAC 112 (70\%) (data not shown). Lima et al. (2006) tested different corn accessions for resistance to fall armyworm and found three that affected larval viability, which could be considered resistant accessions. Silveira et al. (1997) stated that larval viability is not always markedly affected by resistant accessions.

The overall mean duration of the pupal stage of caterpillars fed with the tested popcorn hybrids was 10.5 days. The longest duration of the pupal stage was observed for hybrid IAC 112 and the shortest for hybrid UEM-6. The longest pupal stages were observed in the caterpillars fed with hybrids UEM-2, UEM-3, UEM-4, UEM-7, UEM-8, UEM-9, IAC 112, and JADE during the larval stage (Table 5). Pinheiro et al. (2008) reported a mean pupal stage duration of 9.08 days for caterpillars fed with common corn.

The overall mean pupal mass, measured following $24 \mathrm{~h}$ of metamorphosis, was 0.189 g. Pinheiro et al. (2008) reported a mean pupal mass of $0.219 \mathrm{~g}$. Among the treatments tested on the present experiment, the lowest pupal mass was observed for hybrid UEM-3 and the highest for hybrid UEM-6. The highest mean pupal mass was observed for the caterpillars fed with hybrids UEM-1, UEM-2, UEM-4, UEM-6, UEM-7, UEM-8, UEM-9, IAC 112, and JADE during the larval stage (Table 5). The pupal viability was higher than $80 \%$ for all the hybrids tested. The lowest viability was observed for the caterpillars fed with hybrids UEM-1 and IAC 112, whereas the highest viability was seen with hybrids UEM-2, UEM-3, UEM-4, and UEM-9, which reached 100\% viability (data not shown).

The mean longevity of the adults fed with the tested popcorn hybrids during the larval stage was 4.45 days. The lowest longevity was observed with hybrid UEM-7, and the highest longevity was with hybrid UEM-6 (Table 5). Deformed adults were observed only with three of the 11 hybrids tested, namely UEM-4, UEM-7, and UEM-9. The highest percentage of deformed adults was observed with hybrid UEM-7. Ten percent adult deformity was seen with hybrids UEM-4 and UEM-9. The overall mean duration of the entire life cycle (from egg to adult) of $S$. frugiperda was 36.2 days, and there were no significant differences between the treatments with the 11 popcorn hybrids tested (Table 5).

Egg laying by adults fed with popcorn leaves during the larval stage was only observed in six of the 11 treatments. The mean number of eggs per female was 232.34, and the highest number of eggs per female (504.5) was observed with hybrid UEM-5, while the lowest number was with hybrid UEM-6. Hybrids UEM-2, UEM-4, UEM-7, UEM-8, and IAC 112 did 
not promote egg laying by adults fed with their leaves. Of these hybrids, UEM-4 and UEM-7 showed high potential because they resulted in decreased fall armyworm damage in the field and increased in grain yield and popping expansion (Table 4).

\section{REFERENCES}

Carpentieri-Pípolo V, Takahashi HW, Endo RM, Petek MR, et al. (2002). Correlações entre caracteres quantitativos em milho-pipoca. Hort. Bras. 20: 551-554.

Catapatti TR, Gonçalves MC, Silva Neto MR and Sobroza R (2008). Tamanho de amostra e número de repetições para avaliação de caracteres agronômicos em milho-pipoca. Cienc. Agr. 32: 855-862.

Cruz CD (2013). GENES - a software package for analysis in experimental statistics and quantitative genetics. Acta Sci. Agron. 35: 271-276.

Cruz CD, Regazzi AJ and Carneiro PC (2012). Modelos Biométricos Aplicados ao Melhoramento Genético. Editora UFV, Viçosa, 514.

Cruz I (1995). A Lagarta do Cartucho na Cultura do Milho. EMBRAPA CNPMS, Sete Lagoas, 45.

Cruz I, Gonçalves EP and Figueiredo MLC (2002). Effect of a nuclear polyhedrosis virus on Spodoptera frugiperda (Smith) larvae, its damage and yield of maize crop. Rev. Bras. Milho Sorgo 1: 20-27.

Cunha US, Martins JFS, Porto MP, Garcia MS, et al. (2008). Resistência de genótipos de milho para cultivo em várzeas subtropicais à lagarta-do-cartucho Spodoptera frugiperda. Cienc. Rural 38: 1125-1128.

Daros M, Amaral Júnior AT, Pereira MG, Santos FS, et al. (2004). Correlações entre caracteres agronômicos em dois ciclos de seleção recorrente em milho-pipoca. Cienc. Rural 34: 1389-1394.

Figueiredo MLC, Martins-Dias AMP and Cruz I (2006). Relação entre a lagarta-do-cartucho e seus agentes de controle biológico natural na produção de milho. Pesq. Agr. Bras. 41: 1693-1698.

Gallo D, Nakano O, Silveira Neto S, Carvalho RPL, et al. (2002). Entomologia Agrícola. FEALQ, Piracicaba, 920.

Galvão JCC, Sawazaki E and Miranda GV (2000). Comportamento de híbridos de milho-pipoca em Coimbra, Minas Gerais. Rev. Ceres 47: 201-218.

Hamm JJ and Wiseman BR (1986). Plant resistance and nuclear polyhedrosis virus for suppression of the fall armyworm (Lepidoptera: Noctuidae). Florida Entomologist 69: 541-549.

Lima FWN, Ohashi OS, Souza FRS and Gomes FS (2006). Avaliação de acessos de milho para resistência a Spodoptera frugiperda (Smith) (Lepidoptera: Noctuidae) em laboratório. Acta Amazonica 36: 147-150.

Pereira MG and Amaral Júnior AT (2001). Estimation of genetic components in popcorn based on nested design. Crop Breed. Appl. Biotechnol. 1: 3-10.

Pinheiro JCA, Pádua LEM, Portela GLFP, Branco RTPC, et al. (2008). Biologia comparada de Spodoptera frugiperda (J. E. Smith, 1797) visando ao seu zoneamento ecológico no estado do Piauí. Rev. Caatinga 21: 197-203.

Rangel RM, Amaral Junior AT and Freitas Junior SP (2011). Associação entre características agronômicas e capacidade de expansão em população de milho pipoca sob seleção recorrente. Cienc. Agrotecnol. 35: 225-233.

Sarmento RA, Aguiar RWS, Aguiar RASS, Vieira SMJ, et al. (2002). Revisão da biologia, ocorrência e controle de Spodoptera frugiperda (Lepidoptera, Noctuidae) em milho no Brasil. Biol. J. 18: 41-48.

Scapim CA, Pacheco CAP, Tonet A, Braccini AL, et al. (2002). Análise dialélica e heterose de populações de milho pipoca. Bragantia 61: 219-230.

Seifert AL, Carpentieri-Pípolo V, Ferreira JM and Gerage AC (2006). Análise combinatória de populações de popcorn. Pesq. Agr. Bras. 41: 771-778.

Silveira LCP, Vendramim JD and Rossetto CJ (1997). Efeito de genótipos de milho no desenvolvimento de Spodoptera frugiperda (J.E. Smith). An. Soc. Entomol. Bras. 26: 291-298.

Veloso VRS, Parra JRP and Nakano O (1982). Dados Biológicos Comparativos de Spodoptera frugiperda em (J.E. Smith, 1797) (Lepidoptera: Noctuidae) em Algodoeiro. Anais da Escola de Agronomia e Veterinária da Universidade Federal de Goiás, Goiânia 127-140.

Vendramim JD and Nishikawa MAN (2001). Melhoramento para Resistência a Insetos. In: Recursos Genéticos e Melhoramento: Plantas (Nass LL, ed.). Fundação MT, Rondonópolis, 737-781.

Vieira RA, Rodovalho MA, Scapim CA, Tessmann DJ, et al. (2009). Desempenho agronômico de novos hibridos de milho-pipoca no Noroeste do Estado do Paraná, Brasil. Acta Sci. Agr. 31: 29-36.

Waquil JM and Vilella FMF (2003). Gene bom. Rev. Cult. 49: 22-26.

Waquil JM, Vilella FMF and Foster JE (2002). Resistência do milho (Zea mays L.) transgênico (Bt) à lagarta-do-cartucho, Spodoptera frugiperda (Smith) (Lepidoptera: noctuidae). Rev. Bras. Milho Sorgo 1: 1-11. 